\title{
A new lithostrotian titanosaur (Dinosauria, Sauropoda) from the Early Cretaceous of Transbaikalia, Russia
}

\author{
Alexander Averianov ${ }^{a, b}$ and Pavel Skutschas ${ }^{c}$ \\ a Zoological Institute, Russian Academy of Sciences, Universitetskaya nab., 1, St. Petersburg, \\ 199034, Russian Federation; lepus@zin.ru,dzharakuduk@mail.ru \\ b Department of Sedimentary Geology, Institute of Earth Sciences, Saint Petersburg State Univer- \\ sity, $16^{\text {th }}$ Liniya V. O., 29, St. Petersburg, 199178, Russian Federation \\ c Department of Vertebrate Zoology, Saint Petersburg State University, Universitetskaya nab., 7-9, \\ St. Petersburg, 199034, Russian Federation; p.skutschas@spbu.ru
}

Address correspondence and requests for materials to Alexander Averianov

\begin{abstract}
Tengrisaurus starkovi, gen. et sp. nov., is described based on three caudal vertebrae from the Lower Cretaceous (Barremian?) Murtoi Formation at Mogoito locality, near Gusinoe Lake in Buryatia, Russia. The new taxon is characterized by strongly procoelous anterior and middle caudal vertebrae, with strongly developed pre-epipophyses, highly pneumatic neural spine, and solid bone structure of the centrum. The reweighted phylogenetic analysis places the new taxon as a non-saltasaurid lithostrotian titanosaur (Sauropoda). This is one of the oldest fossil records of Lithostrotia and Titanosauria, which suggests a long and unexplored evolution of titanosaurs in the Early Cretaceous of Asia.
\end{abstract}

Keywords: Dinosauria, Sauropoda, Titanosauria, Lithostrotia, Early Cretaceous, Transbaikalia, Russia

Citation: Averianov, A. and Skutschas, P. 2017 A new lithostrotian titanosaur (Dinosauria, Sauropoda) from the Early Cretaceous of Transbaikalia, Russia. Bio. Comm. 62(1): 6-18. doi: 10.21638/11701/spbu03.2017.102

Author's information: Alexander Averianov, Dr. Sci., Professor, orcid.org/0000-0001-5948-0799, Researcher ID: M-8490-2013; Pavel Skutschas, Ph.D., Ass. Prof., orcid.org/0000-0001-8093-2905, Researcher ID: D-5143-2013

Manuscript Editor: Nikita Zelenkov, Borissiak Paleontological Institute Russian Academy of Sciences, Russia

Received: November 26, 2016;

Revised: January 21, 2017;

Accepted: February 02, 2017;

Copyright: ( 2017 Averianov and Skutschas. This is an open-access article distributed under the terms of the License Agreement with Saint Petersburg State University, which permits to the authors unrestricted distribution and self-archiving free of charge.

Funding: The field work in Transbaikalia in 1998-2002 was funded by the Russian Fund of Basic Researches (grant 98-04-63044) and the National Geographic Society (grant 7089-01). The funders had no role in study design, data collection and analysis, decision to publish, or preparation of the manuscript.

Competing interests: The authors have declared that no competing interests exist.

\section{Introduction}

The first Russian dinosaur, the theropod "Allosaurus" sibiricus, was found in the Lower Cretaceous strata of Transbaikalia (Riabinin, 1914; Ivanov, 1940). During the last century our knowledge of Transbaikalian dinosaurs improved insufficiently (Nesov and Starkov, 1992; Nesov, 1995; Averianov and Skutschas, 2000, 2009; Averianov et al., 2003). However, from what it is known it is clear that sauropods were among the dominant herbivores in the Early Cretaceous of Transbaikalia (Nesov, 1995). Dmitriev (1960) reported on the discovery of a procoelous, apparently caudal sauropod vertebra from the Murtoi Formation at Mogoito locality near Gusinoe Lake in Buryatia (Fig. 1). In 1963, additional excavations at this site produced a sauropod scapula and rib and some other bone fragments (Dmitriev and Rozhdestvensky, 1968). Nesov and Starkov (1992) reported sauropod teeth and procoelous caudal vertebrae from the Mogoito locality. The chisel-like tooth with V-shaped wear facets, identified as cf. Chiayusaurus sp. (ZIN PH 4/13), and the procoelous caudal vertebra (ZIN PH 8/13), have been figured by Nesov (1995:pl. 3, fig. 13, pl. 4, fig. 1). Nesov and Starkov (1992) noted also two osteoderms from Mogoito, which they referred to Armatosauria. These osteoderms cannot be identified in the collection and their attribution to Sauropoda has not been checked. Averianov et al. (2003:figs 5, 6) described and figured a juvenile tooth (ZIN PH 9/13), an adult tooth (ZIN PH 4/13), and two caudal vertebrae (ZIN PH 7/13 and 8/13). All these specimens were identified as Titanosauridae indet. As was already noted (Averianov and Skutschas, 2009:370), the small tooth ZIN PH 9/13 actu- 


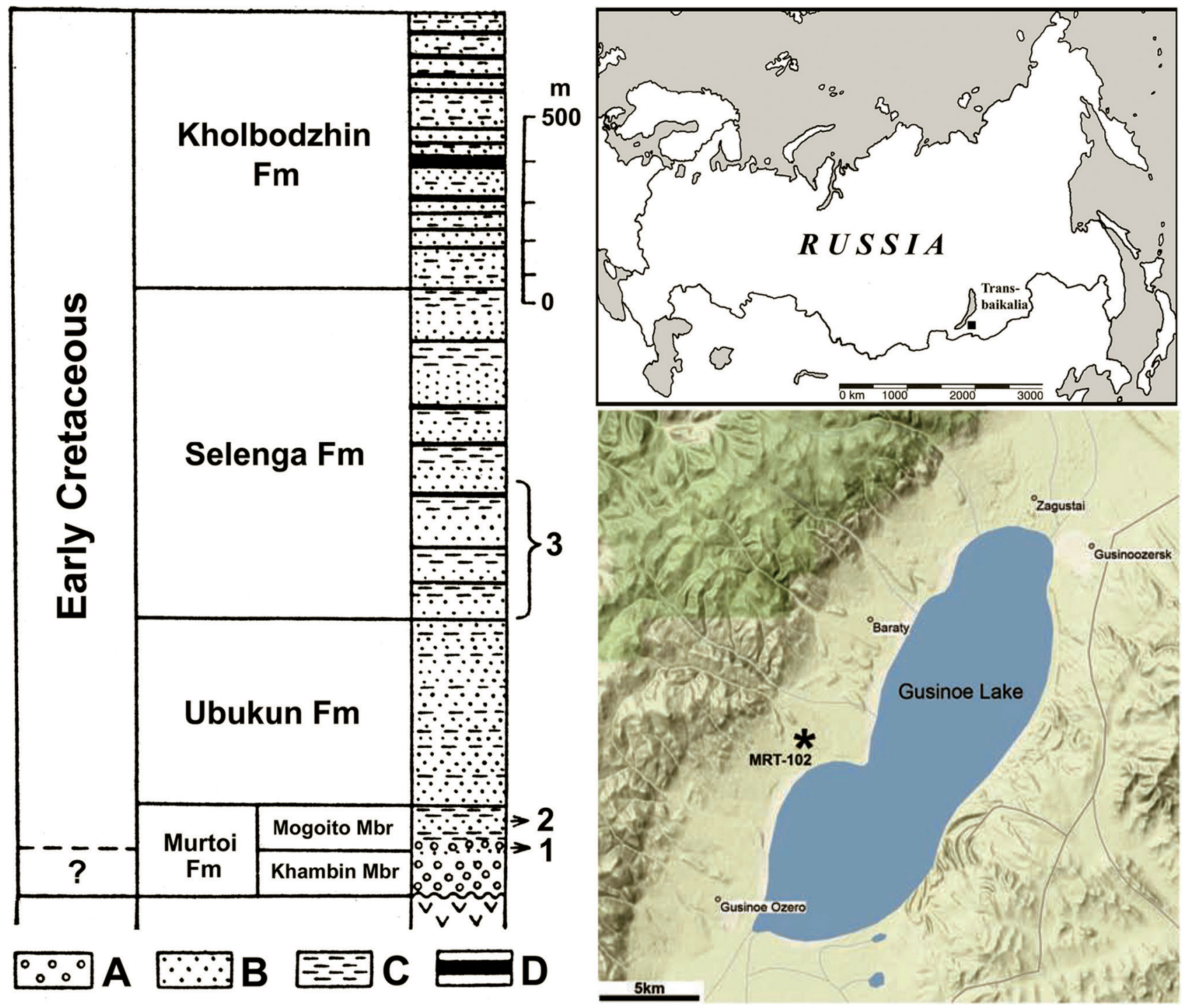

Fig. 1. Geological section (left; modified after Nesov and Starkov, 1992) and geographic position of the Mogoito locality (indicated by a black square on the map of Russia, right top, and by an asterisk on the map of the Gusinoe Lake vicinity, right bottom). Designations: A, conglomerate; B, sandstone; C, clay and black shale; D, coal and clay with coal. 1, level with silificied wood; 2, level with vertebrate remains, including dinosaurs; 3 , upper Aptian level with fish Lycoptera, correlative to the global late Aptian (Clansean) sea transgression.

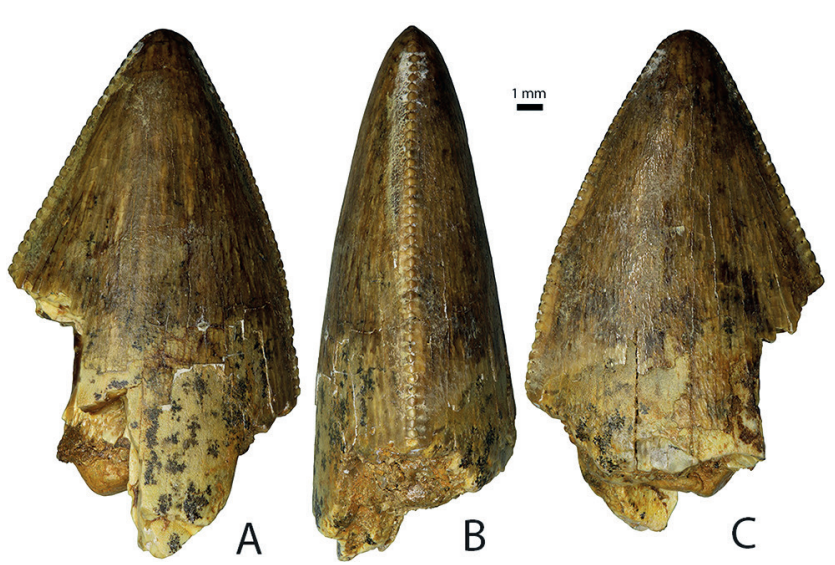

Fig. 2. Theropoda indet., tooth (ZIN PH 5/13), in lateral or medial (A, C) and anterior or posterior (B) views. Mogoito, Buryatia, Russia; Murtoi Formation (Lower Cretaceous, Barremian?). ally belongs to Ornithopoda. One incomplete tooth from Mogoito (ZIN PH 5/13) has been identified as cf. Mongolosaurus and referred to ?Sauropoda (Averianov et al., 2003: fig. 2J). However, this tooth (Fig. 2) likely does not belong to Mongolosaurus (Mannion, 2011). It is provisionally identified here as Theropoda indet. Averianov and Skutschas (2009: fig. 3) described a pencil-like sauropod tooth with high-angled elliptical wear facet from the Lower Cretaceous Khilok Formation at Krasnyi Yar locality in Buryatia, which was referred to Titanosauriformes indet. However, the elliptical wear facets are characteristic for the teeth of derived titanosaurs (Wilson and Sereno, 1998) and the tooth can be attributed to the Titanosauria indet. This tooth is quite different from the sauropod tooth from Mogoito (ZIN PH 4/13), suggesting 


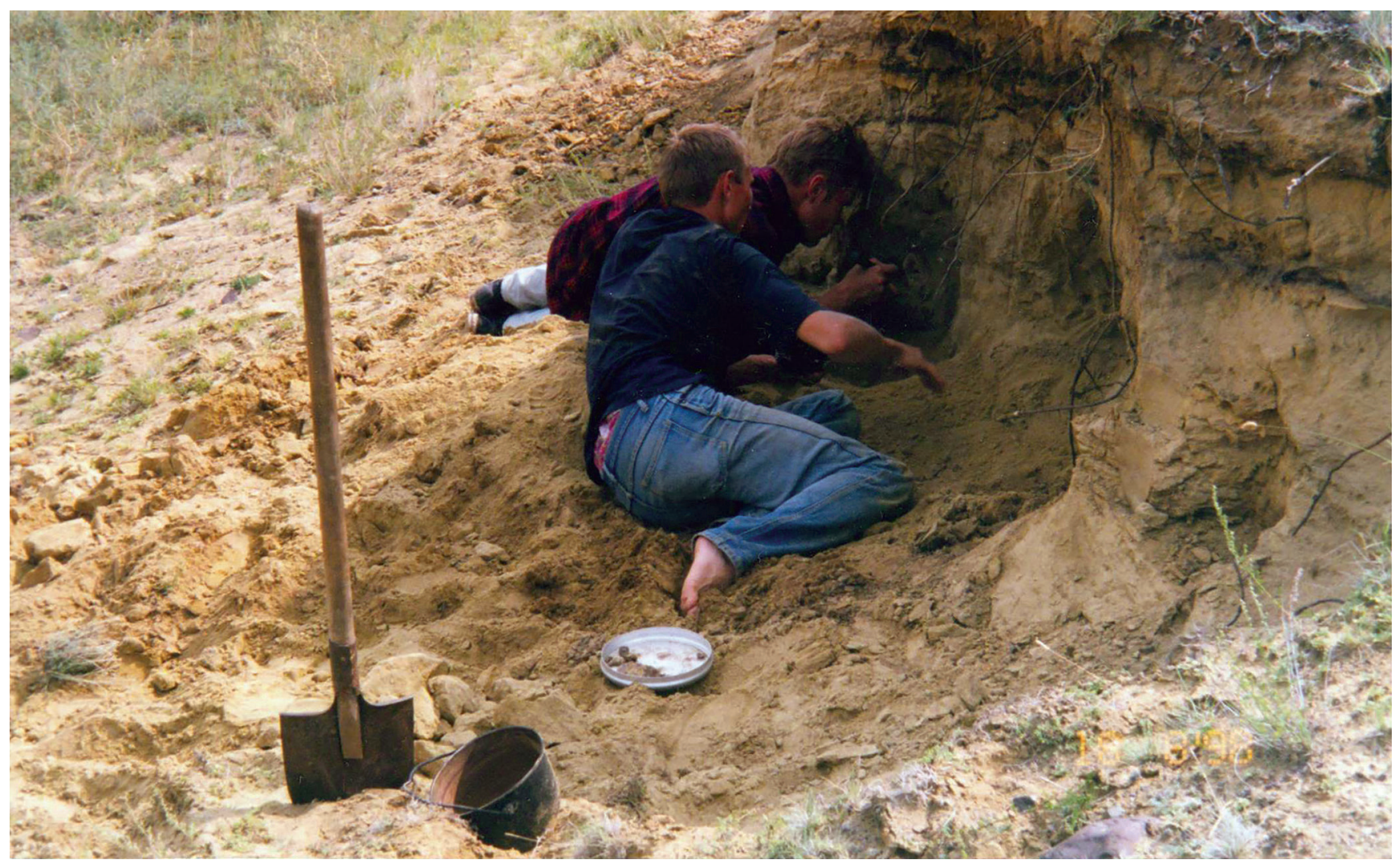

Fig. 3. P. Skutschas and G. Sazonov excavating the anterior caudal vertebra of Tengrisaurus starkovi gen. \& sp. nov. (ZIN PH 14/13) at Mogoito locality in 1998.

that at least two titanosaurian taxa were present in the Early Cretaceous of Transbaikalia. In 1998, an additional sauropod vertebra (ZIN PH 14/13) has been excavated at the Mogoito locality (Fig. 3). The past decade witnessed a tremendous progress in the study of titanosaurian sauropods that allows recognizing the Mogoito sauropod as a distinct taxon. This is only the second dinosaur named from Transbaikalia and the first sauropod from Russia to receive a scientific name.

The described material is housed in the Paleoherpetological collection of the Zoological Institute, Russian Academy of Sciences (ZIN PH).

\section{Systematic palaeontology}

Dinosauria Owen, 1842

Saurischia Seeley, 1887

Sauropoda Marsh, 1878

Titanosauriformes Salgado et al., 1997

Titanosauria Bonaparte et Coria, 1993

Lithostrotia Upchurch et al., 2004

Tengrisaurus gen. nov.

Etymology - From Tengri, the primary chief deity in Mongolian-Turkish mythology, and oaṽpos (Greek), a lizard.
Type species - Tengrisaurus starkovi sp. nov.

Diagnosis - As for the type and only species.

Distribution - Early Cretaceous, Asia.

Tengrisaurus starkovi sp. nov.

Figs 4-6

Etymology - After Alexey Starkov for his generous assistance and contribution to the study of Early Cretaceous vertebrates of Transbaikalia.

Holotype - ZIN PH 7/13, anterior caudal vertebra.

Referred specimens - ZIN PH 14/13, anterior caudal vertebra; ZIN PH 8/13, middle caudal vertebra.

Type locality and horizon - Mogoito, near Gusinoe Lake, Buryatia, Russia; Murtoi Formation, Lower Cretaceous (Barremian-Aptian). See Nesov and Starkov (1992) for discussion of the age.

Diagnosis - Referred to the Lithostrotia because of strongly procoelous anterior and middle caudals. Differs from all other lithostrotians by a unique combination of the following characters: horizontal, anteriorly directed prezygapophyses on anterior caudals; pre-epipophyses projecting anteriorly beyond the prezygapophyseal articular surfaces; a divided interprezygapophyseal lamina of anterior caudal vertebrae; position of postzygapophyses well posterior to the anterior end of the middle cau- 

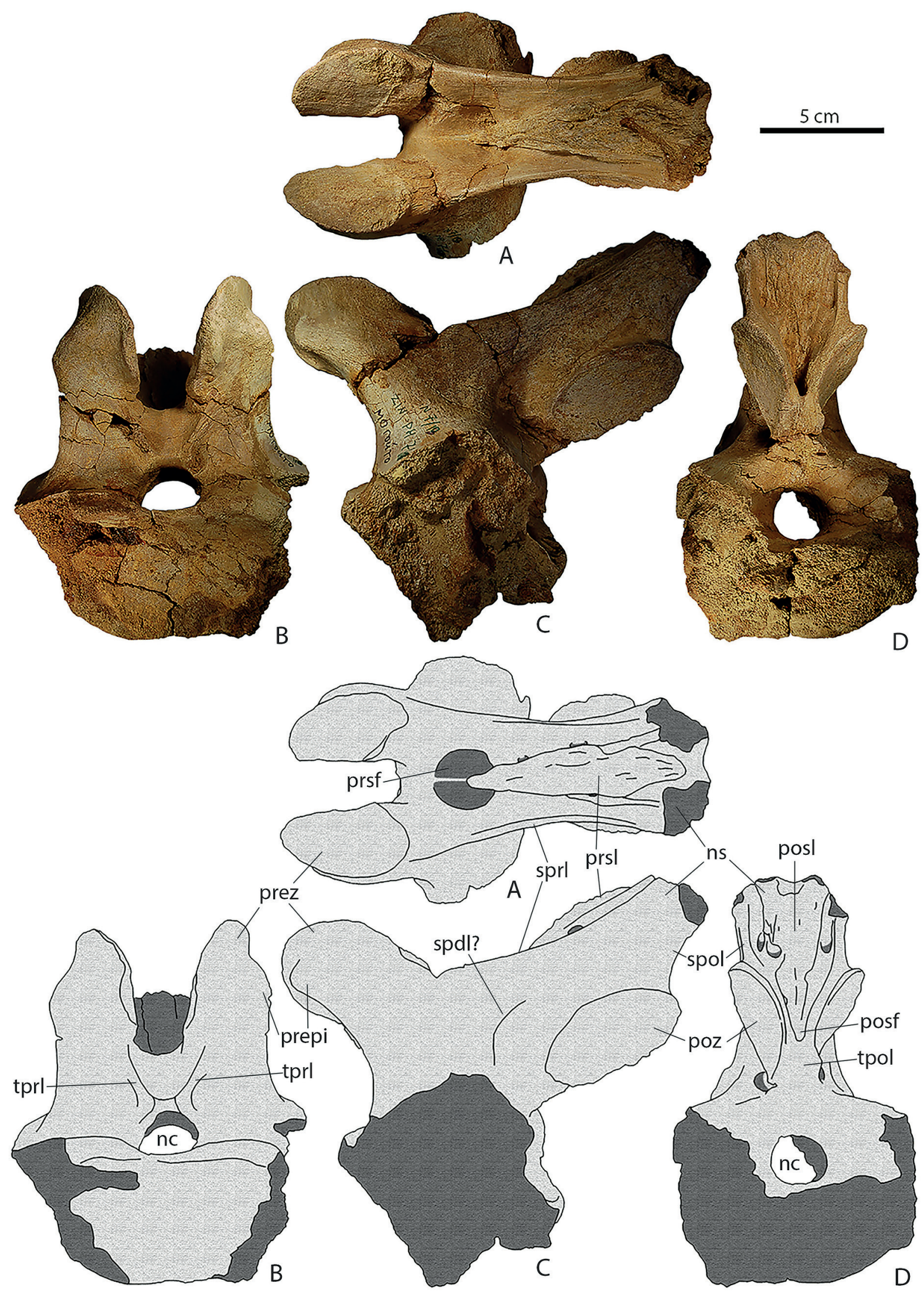

Fig. 4. Tengrisaurus starkovi gen. et sp. nov., ZIN PH 7/13, anterior caudal vertebra (holotype), in dorsal (A), anterior (B), lateral (C), and posterior (D) views; photographs (above) and explanatory drawings (below). Mogoito, Buryatia, Russia; Murtoi Formation (Lower Cretaceous, Barremian?). Abbreviations: nc, neural canal; ns, neural spine; prez, prezygapophysis; prepi, pre-epipophysis; posl, postspinal lamina; posf, postspinal fossa; poz, postzygapophysis; prsf, prespinal fossa; prsl, prespinal lamina; spdl?, spinodiapophyseal lamina?; spol, spinopostzygapophyseal lamina; sprl, spinoprezygapophyseal lamina; tpol, interpostzygapophyseal lamina; tprl, interprezygapophyseal lamina. 

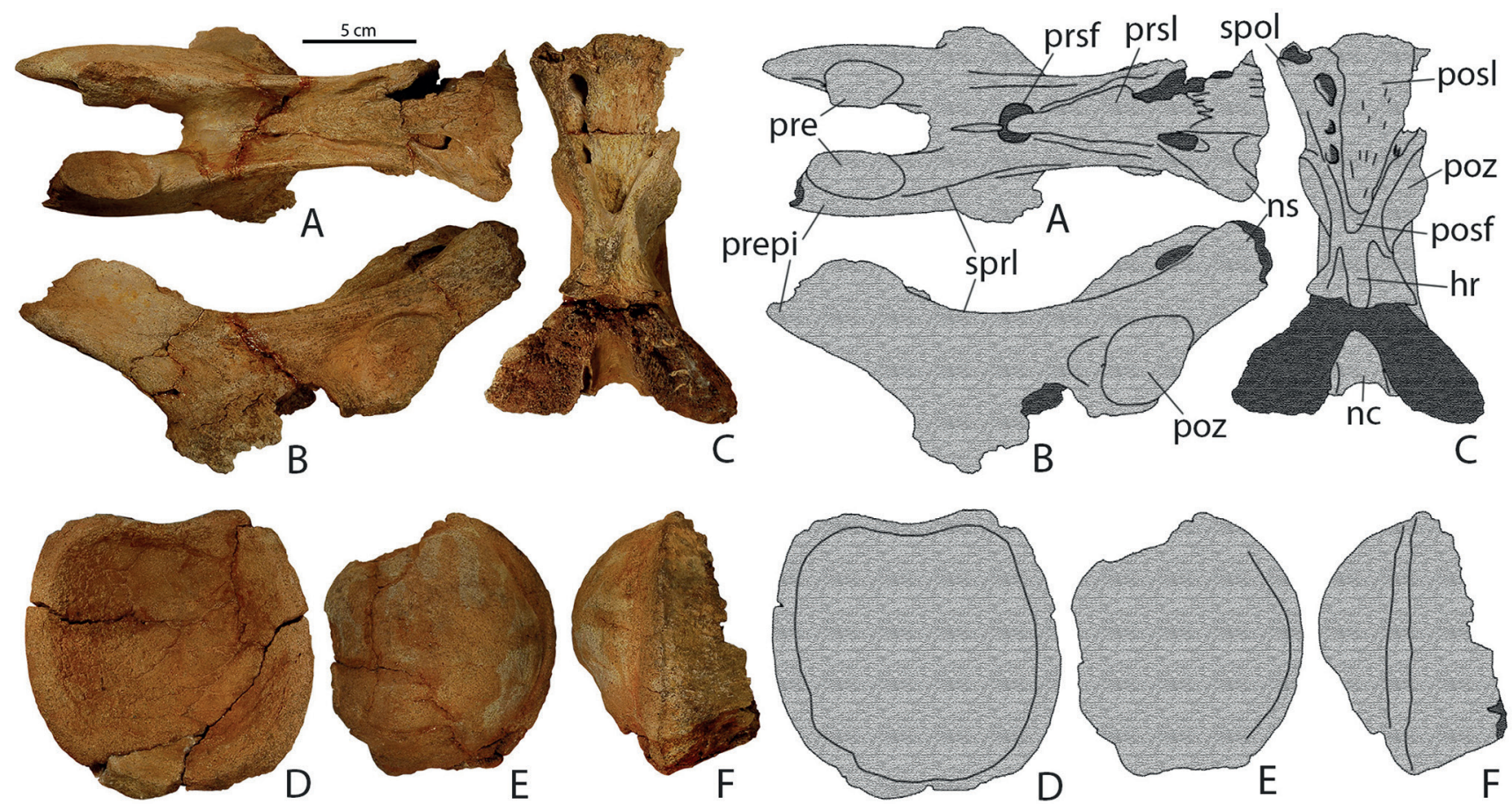

Fig. 5. Tengrisaurus starkovi gen. et sp. nov., ZIN PH 14/13, anterior caudal vertebra, neural arch in dorsal (A), lateral (B), and posteroventral (C) views; centrum in anterior (D), posterior (E), and lateral (F) views; photographs (left) and explanatory drawings (right). Mogoito, Buryatia, Russia; Murtoi Formation (Lower Cretaceous, Barremian?). Abbreviations: hr, hyposphenal ridge; nc, neural canal; ns, neural spine; pre, prezygapophysis; prepi, pre-epipophysis; posl, postspinal lamina; posf, postspinal fossa; poz, postzygapophysis; prsf, prespinal fossa; prsl, prespinal lamina; spol, spinopostzygapophyseal lamina; sprl, spinoprezygapophyseal lamina.
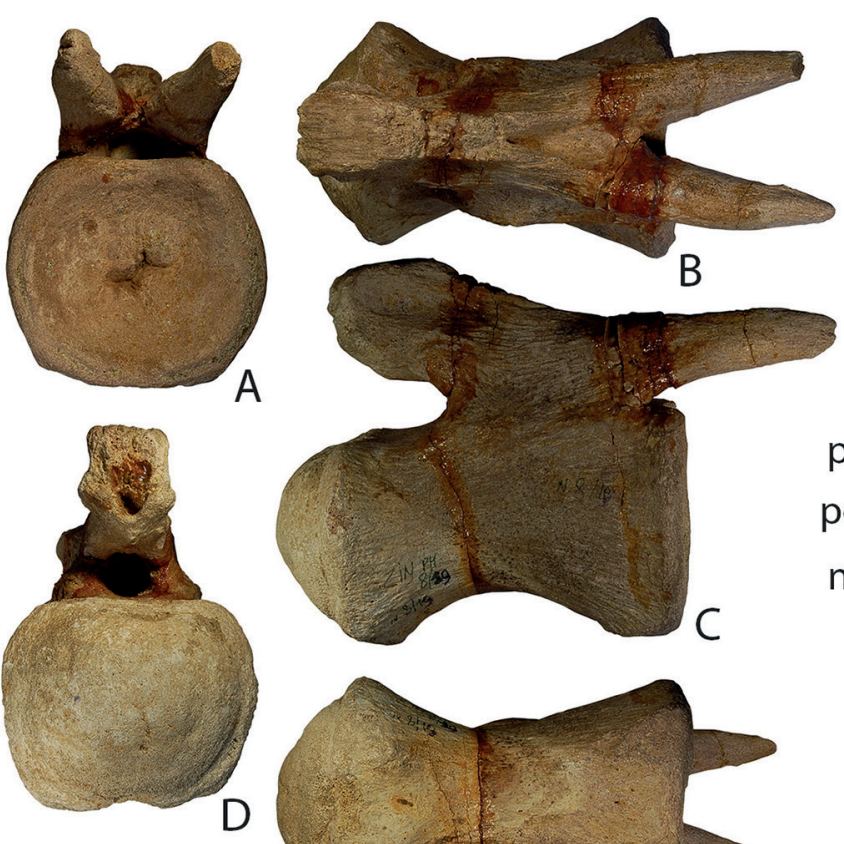

$5 \mathrm{~cm}$
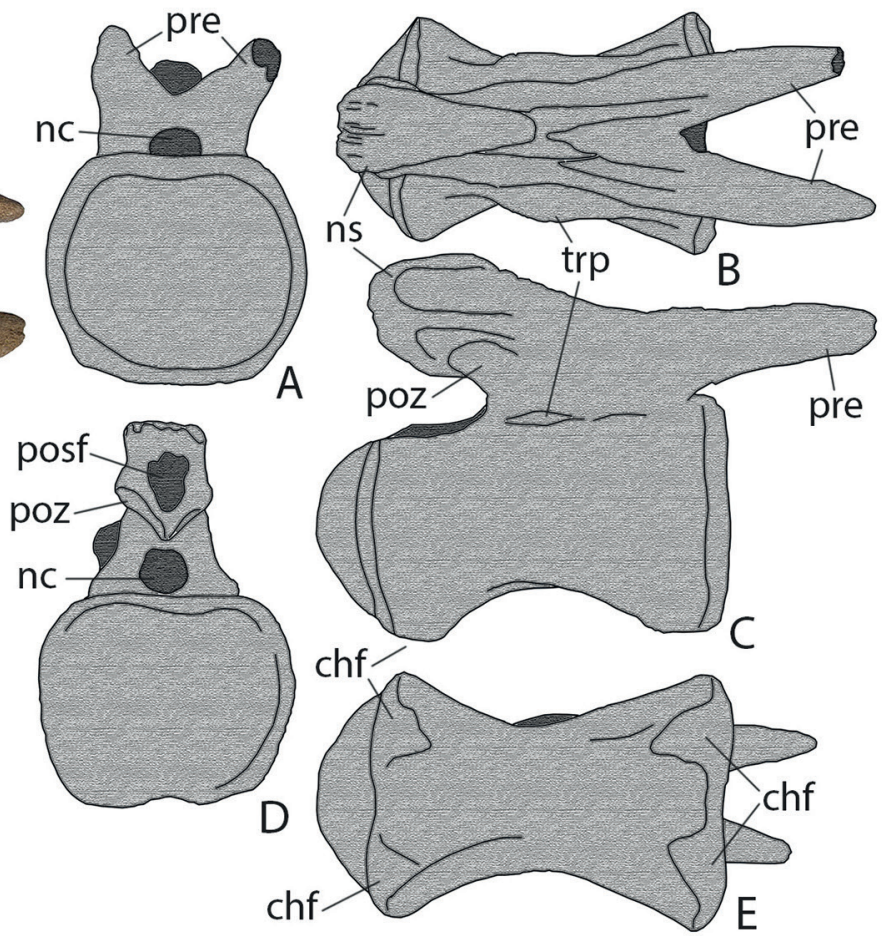

Fig. 6. Tengrisaurus starkovi gen. et sp. nov., ZIN PH 8/13, middle caudal vertebra, in anterior (A), dorsal (B), lateral (C), posterior (D), and ventral (E) views; photographs (left) and explanatory drawings (right). Mogoito, Buryatia, Russia; Murtoi Formation (Lower Cretaceous, Barremian?). Abbreviations: chf, chevron facet; nc, neural canal; ns, neural spine; pre, prezygapophysis; poz, postzygapophysis; posf, postspinal fossa; trp, transverse process. 
dal centrum; neural spine of anterior and middle caudals directed posterodorsally or posteriorly; solid bone structure of the caudal centra.

Differential Diagnosis - Differs from Opisthocoelicaudia by procoelous caudal vertebrae and relatively longer middle caudal vertebrae. Differs from Maxakalisaurus, Gondwanatitan, Trigonosaurus, and Baurutitan by anterior caudal centra not compressed dorsoventrally. Differs from Maxakalisaurus, Neuquensaurus, Saltasaurus, and Rocasaurus by middle and posterior caudal centra not compressed dorsoventrally. Differs from Neuquensaurus by more round articular surfaces of caudal centrum. Differs from Aeolosaurus colhuehuapensis by posterior condyle of caudal centrum dorsally displaced. Differs from Gondwanatitan by posterior condyle of anterior and middle caudal centra not "heartshaped." Differs from Opisthocoelicaudia, Overosaurus, Neuquensaurus, Saltasaurus, and Rocasaurus by the lack of ventral fossa or groove on caudal centrum. Differs from Opisthocoelicaudia, Aeolosaurus, Overosaurus, Trigonosaurus, and Neuquensaurus by horizontal, anteriorly directed prezygapophyses on anterior caudals. Differs from Opisthocoelicaudia, Aeolosaurus, Trigonosaurus, and Lohuecotitan by pre-epipophyses projecting anteriorly beyond the prezygapophyseal articular surfaces. Differs from Trigonosaurus and Neuquensaurus by a divided interprezygapophyseal lamina of anterior caudal vertebrae. Differs from Aeolosaurus colhuehuapensis by lack of infraspinoprezygapophyseal lamina. Differs from Lirainosaurus by the lack of lamina in interzygapophyseal fossa in anterior caudal vertebrae. Differs from Aeolosaurus by position of postzygapophyses well posterior to the anterior end of the middle caudal centrum. Differs from Aeolosaurus by postzygapophyses faced ventrolaterally. Differs from Neuquensaurus by the lack of postzygodiapophyseal lamina (podl). Differs from Rinconsaurus by the lack of long postzygapophyseal processes in middle caudal vertebrae. Differs from Epachthosaurus by the lack of hyposphene-hypantrum articulations in the anterior and middle caudal vertebrae. Differs from Trigonosaurus by a reduced transverse processes in middle caudal vertebrae. Differs from Opisthocoelicaudia, Alamosaurus, Rinconsaurus, Aeolosaurus, Gondwanatitan, Trigonosaurus, and Lohuecotitan by neural spine of anterior and middle caudals directed posterodorsally or posteriorly. Differs from Gondwanatitan by posterior edge of neural spine of anterior and middle caudals placed posterior to the postzygapophyseal articular surface. Differs from Neuquensaurus by transversely wider prespinal and postspinal laminae on anterior caudal vertebrae. Differs from Epachthosaurus by lack of spinodiapophyseal lamina (spdl) on anterior caudal vertebrae. Differs from Maxakalisaurus by an anteroposteriorly short neural spine in middle caudal vertebrae. Differs from Saltasaurus, Rocasaurus and
Neuquensaurus by solid bone structure of the caudal centra.

Remarks - All three sauropod caudal vertebrae referred here to Tengrisaurus starkovi gen. et sp. nov. were found in a close proximity in a small outcrop 5-6 $\mathrm{m}$ in length in a ravine called Promoina Klevenskogo (Fig. 3; Dmitriev and Rozhdestvensky, 1968). The two anterior caudal vertebrae has almost identical morphology of the neural arch and the middle caudal has a morphology expected as a positional variation of these anterior caudals. There are no evidences of more than one sauropod taxon in Mogoito locality and all these three specimens likely belong to one species, if not individual.

\section{Description}

The holotype (ZIN PH 7/13; Fig. 4) is an anterior caudal vertebra missing most of the centrum. The anterior articular surface of the centrum is largely preserved, with missing ventral and lateral edges. There is a prominent concavity along the dorsal margin of the anterior articular surface of the centrum. When the neural canal is horizontally oriented, the anterior articular surface of the centrum is deeply concave, with the centrum of concavity placed at the level of posterior base of the neural arch (Fig. 4C; on this figure, the neural canal is obliquely oriented).

Although the vertebra is incomplete, it is clear that the neural arch was positioned at the anterior end of the vertebra and all the neural arch is confined to the space occupied by the concavity of the centrum anterior articular surface. The anterior border of the neural arch is placed almost on the anterior border of the centrum. The neural canal is oval-shaped, dorsoventrally compressed anteriorly and more round posteriorly (Fig. 4B, D). There is a divided interprezygapophyseal lamina (tprl), oblique ridges that connect the bases of the prezygapophyses with the dorsal margin of neural canal (Fig. 4B). The dorsal margin of the neural canal is bracketed by these ridges. The anterior surface of the neural arch is depressed between the interprezygapophyseal ridge and the poorly defined centroprezygapophyseal lamina (cprl). The centropostzygapophyseal lamina (cpol) is a simple round column. The ventral margins of the postzygapophyses are closely approximated and the interpostzygapophyseal lamina (tpol) is very short transversely but long anteroposteriorly (Fig. 4D). It is separated by a considerable space from the neural canal and there is a longitudinal hyposphenal ridge along this space.

The prezygapophyses projects anteriorly well beyond the centrum. There are well-developed, ridgelike pre-epipophyses on their lateral side (Fig. 4C). The prezygapophyseal articular surfaces are gently convex and oval-shaped, the long axis being anteromediallyposterolaterally oriented. The ventralmost margin of the 
prezygapophyseal articular surface is vertical and set at angle with the rest of the facet. The postzygapophyseal articular surfaces are also oval-shaped, long axis ventromedial-dorsolateral, and convex (more convex on the right side).

Only the base of the transverse process is preserved. Evidently the transverse process was not dorsoventrally expanded. It is anteroposteriorly wide, occupying all the anteroposterior width of the neural arch and likely dorsal part of the centrum. A very weak ridge, which might be a remnant of the spinodiapophyseal lamina, is present only on the left side (spdl?; Fig. 4C).

When the neural canal is horizontally oriented, the neural spine is inclined posteriorly at an angle of $\sim 36^{\circ}$ from the vertical axis. There are high spinoprezygapophyseal laminae (sprl; Fig. 4A, C) between the posterior end of the prezygapophyseal facets and the top of the neural spine (incompletely preserved). These laminae define a large space between the prezygapophyses and the anterior surface of the neural spine. On the lateral side, there is a considerable depression between the spinoprezygapophyseal lamina and the ventral base of the postzygapophyses. In this place, the neural arch is markedly constricted and the distance between the bottoms of these depressions on opposites sides is just about $1 \mathrm{~cm}$. This depression continues dorsally into a shallower groove that extends along the anterior and dorsal margins of the postzygapophyseal facet. The spinopostzygapophyseal laminae (spol; Fig. 4A, D) are very short, shorter than the postzygapophyseal facet.

The prespinal lamina (prsl; Fig. 4A) is well developed, tapers ventrally and intersects the entire prespinal fossa (prsf). The prespinal fossa (prsf; Fig. 4A) is round and deep. The postspinal lamina (posl; Fig. 4D) is also wide and tapers ventrally. There is a deep cleft between the ventral end of postspinal lamina and prezygapophyses, the postspinal fossa (posf; Fig. 4D). Along the lateral edges of the prespinal and postspinal laminae there are several irregular foramina leading to the pneumatic chambers within the neural spine: two on right side and one on left side anteriorly and a single foramen on each side posteriorly, where the right foramen is distinctly larger. The distal end of the neural spine is laterally expanded. The top of the neural spine is saddle-shaped, depressed in the middle and elevated laterally.

The more posterior anterior caudal vertebra, ZIN $\mathrm{PH} 14 / 13$, has preserved the neural arch and anterior and posterior articular surfaces of the centrum (Fig. 5). The contact area between the neural arch and the anterior part of the centrum is partially preserved. The anterior articular surface is oval-shaped, with an incised dorsal margin (Fig. 5D), as in ZIN PH 7/13. It is deeply concave, but its deepest point, in contrast with ZIN PH $7 / 13$, is placed at the level of the middle of the neural arch. The posterior articular condyle of the centrum is ball-like, asymmetrical in lateral view, with the dorsally displaced center (Fig. 5F). A strong ridge circumscribes the posterior condyle. The articular condyle is restricted from the outer margin by a relatively wide flat area. On the posterior side, below the centrum articular surface, there are triangular-shaped chevron facets which face posteriorly. On the ventral side of the centrum there is a prominent longitudinal groove between the chevron facets.

The neural arch of ZIN PH 14/13 is similar to that of ZIN PH 7/13 in size but differs in a number of morphological details. The prezygapophyseal articular surfaces are relatively smaller. The left facet is obliquely oriented and gently convex, as in ZIN PH 7/13. The right facet is smaller than the left one, almost vertically oriented, and flat. On both facets, the ventral most part is set at an angle to the rest of the facet and is vertical. The prominent pre-epipophyses (= nonarticulating anterior processes of D'Emic and Wilson (2011)) extends as rod-like projections anteriorly well beyond the prezygapophyseal facets (Fig. 5A, B). The ventral side of the prezygapophyseal processes is flat, with the prominent medial ridges corresponding to the interprezygapophyseal laminae. These ridges are horizontal, in contrast with the vertical interprezygapophyseal laminae in ZIN PH 7/13, and extend between dorsal margin of neural canal and the base of the prezygapophyseal facets. The prominent grooves separate ventrally the prezygapophyseal facets from the rest of the prezygapophyseal process. Posteriorly there is no space between the neural canal and the postzygapophyseal facets. There is a prominent hyposphenal ridge along the ventral side of the interpostzygapophyseal lamina (Fig. 5C), similar to the ridge placed on ZIN $\mathrm{PH} 7 / 13$ between the neural canal and the interpostzygapophyseal lamina. The postzygapophyseal articular surfaces are about twice smaller than in ZIN PH 7/13 but have a similar shape and similarly concave. The prespinal, postspinal, spinoprezygapophyseal, and spinopostzygapophyseal laminae are developed as in ZIN $\mathrm{PH} 7 / 13$. The prespinal fossa is relatively smaller and shallower (Fig. 5A). Along the prespinal lamina there is one pneumatic foramen in the middle of the right side and much larger foramen at the distal end of the left side. The top of the neural spine is broken on the right side revealing a large pneumatic chamber between prespinal and postspinal laminae separated by a midline septum from the chamber on the left side. There are three pneumatic foramina drastically decreasing in size distally, along the left side of the postspinal lamina. On the right side, only proximal of these foramina is present. The distal end is laterally expanded, as in ZIN PH 7/13. In contrast to the latter specimen, it is not saddle-shaped but has a medial eminence formed by the prespinal and postspinal laminae and lateral projections formed by spinoprezygapophyseal and spinopostzygapophyseal 
Table 1. Measurements (in mm) of caudal vertebrae of Tengrisaurus starkovi gen. et sp. nov. Mogoito, Buryatia, Russia; Murtoi Formation (Lower Cretaceous, Barremian?)

\begin{tabular}{|c|c|c|c|}
\hline Measurements & ZIN PH 7/13 & ZIN PH 14/13 & ZIN PH 8/13 \\
\hline $\mathrm{ACH}$, anterior height of centrum & & 127.2 & 78.6 \\
\hline ACW, anterior width of centrum & & 124.6 & 88.5 \\
\hline ANW, anterior width of neural arch (between lateral margins of prezygapophyses) & 94.7 & 73.0 & 56.1 \\
\hline $\mathrm{CL}$, centrum length (ventral) & & & 135.0 \\
\hline $\mathrm{PCH}$, posterior height of centrum & & 119.0 & 71.2 \\
\hline PCW, posterior width of centrum & & & 84.6 \\
\hline PNW, posterior width of neural arch (between lateral margins of postzygapophyses) & 68.3 & & 32.7 \\
\hline
\end{tabular}

laminae. There are distinct depressions between these median eminence and lateral projections.

ZIN PH $8 / 13$ is a complete middle caudal vertebra (Fig. 6). The centrum articulation is procoelous, with deeply convex anterior articular surface and ball-like, laterally asymmetrical (dorsally displaced) posterior condyle. As in ZIN PH 14/13, there is a strong ridge circumscribing the posterior condyle and the condyle is restricted from the outer margin by a flat area. The height of the centrum articular surfaces are slightly smaller than their width (Table 1). The centrum is constricted laterally and ventrally at the middle. The ventral side is deeply arched in lateral view. The ventral surface of the centrum is somewhat flattened at the middle and has shallow anterior and posterior longitudinal grooves separating the small triangular chevron facets that face ventrally.

The neural arch of ZIN PH 8/13 is confined to the anterior half of the centrum. The deepest point of the anterior articular surface is placed at the level of the anterior end of neural canal dorsal roof. On the neurocentral suture, which is completely closed, there is a ridgelike remnant of the transverse process, which occupies the posterior third of the neural arch (Fig. 6C). The prezygapophyses are long rod-like processes extending anteriorly well beyond the centrum (Fig. 6B, C). On the right process there is a poorly defined, longitudinally elongated, and flat prezygapophyseal articular surface. The postzygapophyseal articular surface is better developed on the left side (Fig. 6C). It is small, facing ventrolaterally, but still concave. There are poorly developed prespinal and postspinal laminae separated by flattened and laterally expanded horizontal plate at the top of neural spine. The spinoprezygapophyseal laminae are nearly horizontal and not fused posteriorly. There is a considerable space between the prespinal lamina and anterior end of the neural canal roof, with a shallow prespinal fossa between the spinoprezygapophyseal laminae. The postspinal fossa is small but still deep (Fig. 6D).

The bone structure of the centrum ZIN PH 7 and $14 / 13$, revealed by breakage, is solid, with many tiny cells uniformly distributed. The size of the cells is not greater than 1-3 mm. The centrum of ZIN PH 8/13 is not broken but likely has a similar bone structure.

Interpretation of vertebrae - The holotype vertebra (ZIN PH 7/13) is certainly not the first or second caudal because its transverse process is not expanded dorsoventrally. By relatively large neural arch and anteroposteriorly wide transverse process, which base occupies all the neural arch, it is similar to the third caudal of Neuquensaurus australis (Salgado et al., 2005: fig. 6C). However, in ZIN PH 7/13 the transverse process is positioned mostly on the neural arch, while in the third caudal of N.australis it is on the dorsal half of the centrum (D'Emic and Wilson, 2011: fig. 6A1). This suggests a more posterior position of ZIN PH 7/13 within the caudal series.

By the overall proportions ZIN PH 8/13 fits the caudal vertebrae 17-18 in the complete caudal series of Baurutitan britoi (Kellner et al., 2005: fig. 19).

Measurements - See Table 1.

\section{Phylogenetic analysis}

For the phylogenetic analysis we used recent matrix of sauropods, focused on Titanosauriformes, presented by Lacovara et al. (2014). The matrix included 74 taxa and 341 characters. Eleven uninformative characters (3.2\%). The multistate characters $12,58,95,96,102,106,108$, $115,116,119,120,154,164,213,216,232,233,234,235$, 256, 267, 298, 299, and 301 are ordered. Tengrisaurus gen. nov. can be scored by 18 characters (5.3\%). See Appendix 1 for the scored characters.

The character-taxon matrix was analyzed using PRAP, parsimony ratchet analysis using PAUP (Müller, 2007), and PAUP ${ }^{\star} 4.0$ b10 (Swofford, 2002). The equalweight analysis with 10,000 ratchet replications produced 544 most parsimonious trees; the tree statistics is presented in Table 2. The strict consensus tree finds little resolution among Titanosauriformes. To increase resolution and recover any phylogenetic signal, a successive weighting analysis (Farris, 1969) was conducted. Using PAUP, the characters were reweighted by the maximum value of rescaled consistency indices (RC), and a heuristic search with 10,000 random sequence addition repli- 


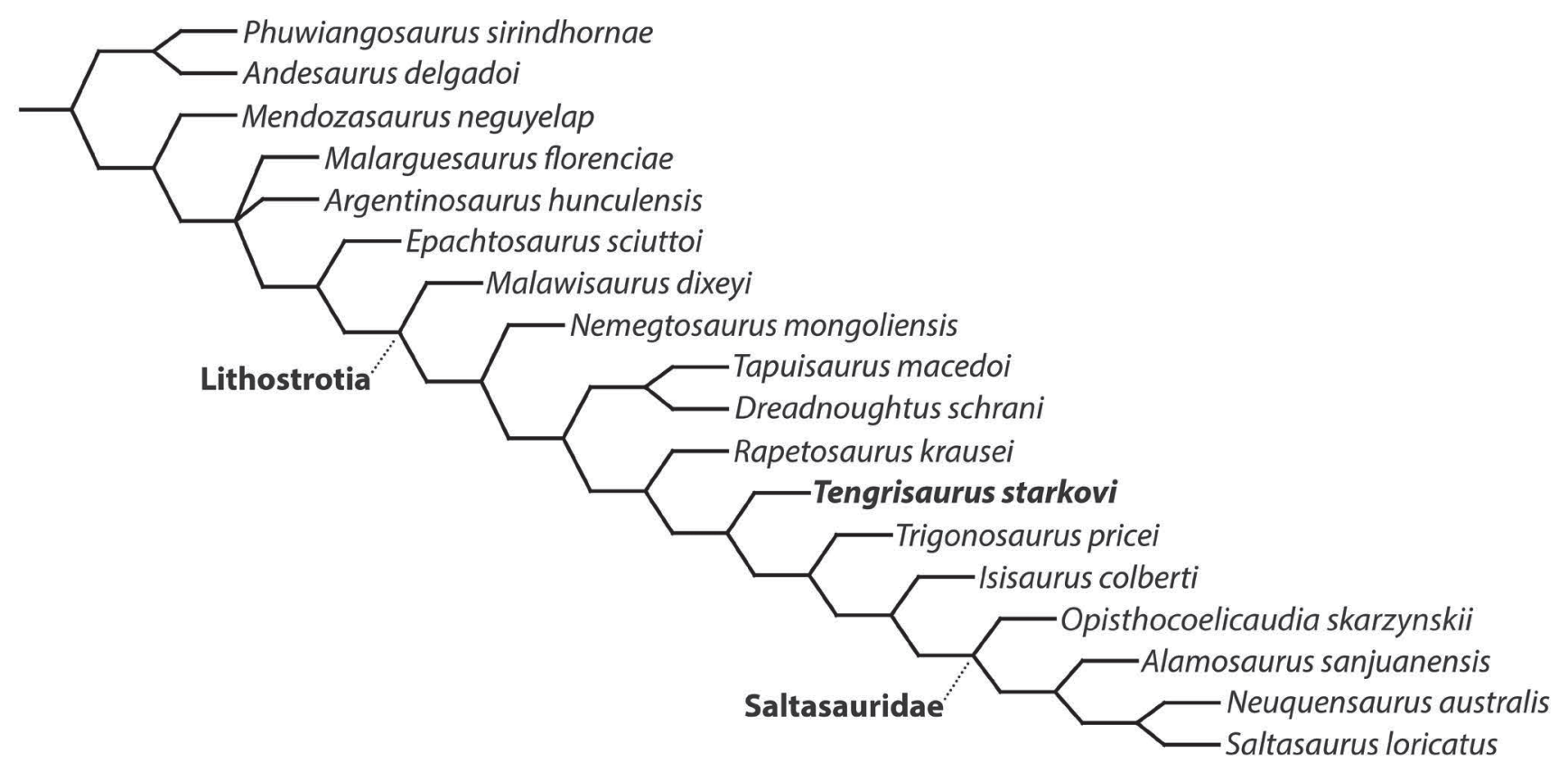

Fig. 7. Part of the strict consensus tree of 171 most parsimonious trees produced by PAUP reweighting character analysis (see text), showing the interrelationships of Titanosauria including Tengrisaurus gen. nov.

Table 2. Statistics for equal weight (PRAP and PAUP) and reweight (PAUP) analyses

\begin{tabular}{l|c|c|c|c}
\hline \multicolumn{1}{c|}{ Parameters } & Equal weight analysis & Reweight analysis 1 & Reweight analysis 2 & Reweight analysis 3 \\
\hline N, number of trees & 544 & 133 & 171 & 171 \\
L, tree length & 1056 & 300.9 & 298.5 & 298.5 \\
Cl, consistency index & 0.389 & 0.636 & 0.649 & 0.649 \\
HI, homoplasy index & 0.611 & 0.346 & 0.355 & 0.355 \\
RI, retention index & 0.278 & 0.544 & 0.554 & 0.554 \\
RC, rescaled consistency index & 0.245 & 0.419 & 0.422 & 0.422 \\
\hline
\end{tabular}

cates and TBR (tree bisection and reconnection) branch swapping was performed. During reweighting 227 characters $(66.6 \%)$ got a weight of less than 1 . Tree statistics stabilized after three successive runs of the reweight analysis (Table 2). A section of the strict consensus of 171 trees obtained in the last analysis, showing the interrelationships of Titanosauria, is illustrated in Fig. 7. The phylogenetic analysis reveals Tengrisaurus as a nonsaltasaurid lithostrotian titanosaur.

\section{Synapomorphies of Tengrisaurus and other titanosaurs}

Centrum articulations of caudal vertebrae - In Tengrisaurus the anterior and middle caudal vertebrae are strongly procoelous, with deeply concave anterior articular surface (cotyle) and a hemispherical posterior articular "ball" (condyle). The procoelous anterior caudal vertebrae is a synapomorphy of Titanosauria (Wilson, 2002: character 118) or Lithostrotia (D’Emic, 2012: char- acter 55). The procoelous middle and posterior caudal vertebrae is a synapomorphy for a more exclusive clade within the Titanosauria: Nemegtosauridae + (Isisaurus + Saltasauridae) (Wilson, 2002: character 134) or Alamosaurus + Saltasaurini (D'Emic, 2012: character 61). In our analysis the last character (210(3)) is present in a clade containing Epachthosaurus and more derived taxa, but reversed in Malawisaurus. Lithostrotia was defined as a node-based taxon containing the most recent common ancestor of Malawisaurus and Saltasaurus and all the descendants of that ancestor and diagnosed by strongly procoelous proximal caudal centra and the presence of strong procoely in all except the most distal caudals (Upchurch et al., 2004: character 311). This phylogenetic definition of the clade contradicts its diagnosis because in Malawisaurus the middle and posterior caudal vertebrae are not procoelous (Gomani, 1999, 2005).

Ventral depression on caudal centra - In the middle caudal vertebra of Tengrisaurus (ZIN PH 8/13) the ventral centrum surface is round in the transverse 
cross-section, without a longitudinal groove or depression. The centrum of the anterior caudal vertebrae ZIN $\mathrm{PH}$ 14/13 is incompletely preserved. It has shallow longitudinal grooves anteriorly and posteriorly, between the chevron facets. Anterior and middle caudal centra with ventral longitudinal hollow was considered a synapomorphy of Titanosauria (Wilson, 2002: character 132; D'Emic, 2012: character 54). Presence of such a hollow in the middle caudal centra is a synapomorphy for the clade Lirainosaurus + Saltasauridae in the analysis by Curry Rogers (2005: character 230), but the character is reversed in the node containing Magyarosaurus, Malawisaurus, Nemegtosaurus, and $\mathrm{Ra}$ petosaurus. In our analysis this character (209:1) is a synapomorphy for the clade containing Trigonosaurus and more derived taxa, but evolved in parallel in Epachthosaurus and Malawisaurus. This character is partially correlated with the presence of ventrolateral ridges on the centrum that bound a ventral fossa (character 196 in our analysis). The ventrolateral ridges are present in a number of titanosaurs that have the ventral fossa, including Alamosaurus and Neuquensaurus (D'Emic and Wilson, 2011). In our analysis the character 196:1 is a synapomorphy for the clade containing Isisaurus and more derived taxa.

Apex of centrum posterior condyle displaced dorsally - This condition is present in anterior and middle caudal vertebrae of Tengrisaurus. Most lithostrotians have a similar condition, except two species of Aeolosaurus, where the apex is closer to the centrum midline (Santucci and De Arruda-Campos, 2011).

Chevron facets facing posteriorly - In Tengrisaurus the posterior chevron facets of the anterior caudal vertebra (ZIN PH 14/13) face mostly posteriorly, while on the middle caudal vertebra (ZIN PH 8/13) both anterior and posterior chevron facets face ventrally.

Neural arch position on the centrum - In Tengrisaurus the neural arch of the holotype anterior caudal vertebra and the middle caudal vertebra (ZIN PH 8/13) is located on the anterior half of the centrum. This character is a synapomorphy of Titanosauriformes (Curry Rogers, 2005: character 235; D’Emic, 2012: character 58).

Caudal transverse process disappearance - In the middle caudal ZIN PH 8/13 of Tengrisaurus the transverse process is reduced to a ridge-like bump. In most eusauropods the caudal transverse processes disappeared by caudal 15, but in some titanosaurs, for example Opisthocoelicaudia and Alamosaurus, it disappeared by caudal 10 (Wilson, 2002: character 115). Trigonosaurus represents a striking departure from this trend. In this taxon, the transverse process is clearly distinct at least up to the 20th caudal (Campos et al., 2005). Also in Saltasaurus the transverse process is not reduced in the middle caudals (Powell, 1992: fig. 23).
Fossa between the transverse process and neural spine - In the holotype vertebra there is a deep fossa between the transverse process and the neural spine, anteroventral to the postzygapophyseal facet. In a more posterior caudal, ZIN PH 14/17, this fossa is much less pronounced. A similar fossa, termed the interzygapophyseal fossa, is present in the anterior caudals of Adamantisaurus, Aeolosaurus, Lirainosaurus, Malawisaurus, Mendozasaurus, and Petrobrasaurus (Sanz et al., 1999; González Riga, 2003; Powell, 2003; Gomani, 2005; Santucci and Bertini, 2006; Casal et al., 2007; Filippi et al., 2011). The interzygapophyseal fossa is usually more dorsal in position compared with the holotype vertebra, placed anteriorly to the postzygapophyseal facet. In $\mathrm{Li}$ rainosaurus there is a lamina intersecting the interzygapophyseal fossa (Sanz et al., 1999). In Normanniasaurus there is a foramen in the position of the interzygapophyseal fossa (Le Loeuff et al., 2013).

Pre-epipophysis - Pre-epipophysis is a ridge on the prezygapophysis placed on the side opposite to the prezygapophyseal articulation facet. It is present on the cervical vertebrae of various sauropods and is common in titanosauriforms (Wilson and Upchurch, 2009; Whitlock, 2011; Tschopp et al., 2015). Such ridge is present on the holotype caudal vertebra of Tengrisaurus. In ZIN PH 14/18 the pre-epipophysis is more developed and forms an anterior process projecting beyond the prezygapophyseal articular process. This non-articulating anterior processes on the middle caudal vertebrae were considered as an autapomorphy of Neuquensaurus australis by D'Emic and Wilson (2011).

Postzygapophyses concave - In Aeolosaurus and Gondwanatitan the articular surfaces of the postzygapophyses in anterior caudals are relatively large and form a pronounced concavity, which extends ventrally forming a "half-cylinder" that partially encloses the prezygapophyses of the following vertebra (Kellner and de Azevedo, 1999). A similar condition is observed in Tengrisaurus, though in that taxon the concavity of the postzygapophyseal facets is less pronounced.

Hyposphenal ridge - The hyposphenal ridge extends from the ventral midline junction of the postzygapophyses to the top of the neural canal (Upchurch, 1998). It is present in the anterior caudal vertebrae of many sauropods except derived somphospondylans and most rebbachisaurids (Upchurch, 1998; Upchurch and Martin, 2003; Upchurch et al., 2004; Mannion et al., 2013). A weak hyposphenal ridge is present in both anterior caudals of Tengrisaurus. In our analysis this character (203:1) is present in few not-related taxa.

Postspinal fossa - The postspinal fossa is positioned on the posterior side of the neural spine between the spinopostzygapophyseal laminae laterally and interpostzygapophyseal lamina ventrally. Presence of a postspinal fossa in anterior caudal vertebrae has been con- 
sidered a synapomorphy for the clade containing $\mathrm{Ma}$ lawisaurus, Nemegtosaurus, and Rapetosaurus (Curry Rogers, 2005: character 221).

Neural spine transverse breath - In Tengrisaurus the neural spine of the holotypic vertebra is not complete laterally; the preserved transverse breadth is $\sim 1.5$ times greater than the anteroposterior length. In the other anterior caudal vertebra, ZIN PH 14/13, the apex of the neural spine is complete from the left side. It has the transverse breadth $\sim 2.1$ times greater than the anteroposterior length. The neural spine transverse breadth greater than anteroposterior length in anterior caudals was considered a synapomorphy for the clade Isisaurus + Saltasauridae (Wilson, 2002: character 126). The neural spine of anterior caudals is expanded laterally in Aeolosaurus, Adamantisaurus, and Trigonosaurus (Campos et al., 2005; Santucci and Bertini, 2006; Santucci and De Arruda-Campos, 2011). In our analysis this character (199:1) is a synapomorphy for the clade including Tengrisaurus and more derived taxa.

Neural spine inclination - In Tengrisaurus the neural spine is inclined posterodorsally in the holotype vertebra and more posteriorly in ZIN PH 14/13. In the middle caudal ZIN PH 8/13, the neural spine is very short and its inclination is difficult to assess. Salgado et al. (2005) considered a strongly posteriorly directed neural spine of caudal vertebrae posterior to the first caudal a synapomorphy for the Saltasaurinae. In other titanosaurs the neural spine is vertical, or even anteriorly inclined.

Neural spine anterior edge position - In the middle caudal vertebra of Tengrisaurus, ZIN PH 8/13, the sloping anterior margin of the neural spine is placed mostly anterior to the postzygapophyseal facet. The anterior border of the neural spine located posteriorly with respect to the anterior margin of the postzygapophyses in the middle caudals has been considered a synapomorphy for Saltasaurinae (Salgado et al., 1997).

Neural spine pneumatic openings - In the anterior caudal vertebrae of Tengrisaurus there are irregular pneumatic openings on the neural spine along the lateral margins of the prespinal and postspinal laminae. Similar openings in anterior and middle caudal vertebrae have been reported for Bonatitan, Baurutitan, Futalognkosaurus, Neuquensaurus, and Saltasaurus (Powell, 2003; Martinelli and Forasiepi, 2004; Kellner et al., 2005; Calvo et al., 2008; D'Emic and Wilson, 2011).

Osseous tissue structure - The term spongy bone is sometimes used as a synonym of the camellate bone structure (Wilson and Sereno, 1998; García and Salgado, 2013). Wilson (2002) distinguished between the spongy bone, with centimetre-scale internal cells, "semicamellate" according to Wedel et al. (2000), and camellate to somphospondylous bone structure, with subcentimetrescale cells. Such definition of the spongy bone as having centimetre-scale internal cells is confusing, as in a sponge (both plastic tool and its living prototype) the internal cells are very small, usually not greater than $1 \mathrm{~mm}$. The centrum bone structure of the caudal vertebrae in Tengrisaurus looks exactly as in a sponge, with small internal cells, not greater than 1-3 mm. This condition is considered here the solid bone structure. We refrain from using the term "spongy bone" to avoid confusion. The bone structure of the neural arch in caudal vertebrae of Tengrisaurus, at least partially, is camellate (= somphospondlyus), with large internal cells.

The pneumatization of the caudal centra have increased in the evolution of Saltasaurinae. In Saltasaurus, Rocasaurus, and Neuquensaurus, the caudal centra have camellate bone structure (Powell, 1992; Salgado and Azpilicueta, 2000; Cerda et al., 2012; García and Salgado, 2013).

\section{General discussion}

The understanding of the evolutionary history of Titanosauria is hampered by the lack of an explicit and reliable phylogenetic hypothesis. The content of Titanosauria and the phylogenetic relationships within this taxon greatly varies between studies (D'Emic, 2012; Mannion et al., 2013). The most recent comprehensive study of the titanosaurian interrelationships based on the Bayesian analysis revealed quite different phylogeny of the group (Gorscak and O'Connor, 2016). This analysis postulate Gondwanan origin of the Titanosauria in the Early Cretaceous in South America. However, the analysis does not include taxa from the Early Cretaceous of Asia, like possible non-saltasaurid lithostrotian Daxiatitan from the Aptian of China (You et al., 2008; Averianov and Sues, 2017). Tengrisaurus gen. nov. is another Asian nonsaltasaurid lithostrotian which age (Barremian-Aptian?) is coeval with the other oldest records of Titanosauria. Presence of derived lithostrotian titanosaurs in the Early Cretaceous of Asia suggests earlier dates of divergence of main titanosaurian clades and possible origin of the group in Asia.

\section{Acknowledgements}

We thank N.G.Borisova and G.I.Sazonov for the logistical support, A. V.Abramov and A. I. Starkov for the generous assistance during the field work in 1998 and 1999. We are grateful to I.A.Cerda, M.D.D'Emic, and an anonymous reviewer for reviewing the paper and useful suggestions.

\section{References}

Averianov, A. O., and Skutschas, P.P. 2000. Kompleks pozvonochnykh rannego mela Zabaikalya [A vertebrate assemblage from the Early Cretaceous of Transbaikalia (locality Mogoito)]; pp. 357-358 in A. V. Komarov (ed.), Materials of the Regional Conference of the Geologists of Siberia, Far East and North East of Russia. GalaPress, Tomsk.

Averianov, A. O., and Skutschas, P.P. 2009. Additions to the Early Cretaceous dinosaur fauna of Transbaikalia, eastern Russia. Proceed- 
ings of the Zoological Institute of the Russian Academy of Sciences 313:363-378.

Averianov, A. O., Starkov, A. I., and Skutschas, P.P. 2003. Dinosaurs from the Early Cretaceous Murtoi Formation in Buryatia, Eastern Russia. Journal of Vertebrate Paleontology 23:586-594.

Averianov, A. O., and Sues, H.-D. 2017. Review of Cretaceous sauropod dinosaurs from Central Asia. Cretaceous Research 69:184-197.

Calvo, J. O., Porfiri, J.D., González Riga, B. J., and Kellner, A.W.A. 2008. Anatomy of Futalognkosaurus dukei Calvo, Porfiri, González Riga, and Kellner, 2007 (Dinosauria, Titanosauridae) from the Neuquén Group (Late Cretaceous, Patagonia, Argentina. Arquivos do Museu Nacional, Rio de Janeiro 65:511-526.

Campos, D. A., Kellner, A. W.A., Bertini, R. J., and Santucci, R. M. 2005. On a titanosaurid (Dinosauria, Sauropoda) vertebral column from the Bauru Group, Late Cretaceous of Brazil. Arquivos do Museu Nacional, Rio de Janeiro 63:565-593.

Casal, G.A., Martínez, R.D., Luna, M., Sciutto, J.C., and Lamanna, M.C.2007. Aeolosaurus colhuehuapensis sp. nov. (Sauropoda: Titanosauria) de la Formación Bajo Barreal, Cretácico Superior de Argentina. Revista brasileira de Paleontologia 10:53-62.

Cerda, I.A., Salgado, L., and Powell, J.E.2012. Extreme postcranial pneumaticity in sauropod dinosaurs from South America. Paläontologische Zeitschrift 86:441-449.

Curry Rogers, K.A.2005. Titanosauria: a phylogenetic overiview; pp. 50193 in Curry Rogers, K.A., and Wilson, J.A. (eds.), The Sauropods. Evolution and Paleobiology. University of California Press, Berkeley, Los Angeles, London.

D'Emic, M. D. 2012. The early evolution of titanosauriform sauropod dinosaurs. Zoological Journal of the Linnean Society 166:624-671.

D'Emic, M.D., and Wilson, J.A.2011. New remains attributable to the holotype of the sauropod dinosaur Neuquensaurus australis, with implications for saltasaurine systematics. Acta Palaeontologica PoIonica 56:61-73.

Dmitriev, G.A.1960. Novye nakhodki dinozavrov v Buryatii [New findings of dinosaurs in Buryatia]. Paleontologicheskii Zhurnal 1:148.

Dmitriev, G.A., and Rozhdestvensky, A. K. 1968. Kostenosnye fatsii ozerno-rechnykh otlozhenii verkhnego mezozoya Muryatii [Bone bearing facies of lacustrine-fluvial deposits of the upper Mesozoic of Buryatia]; pp. 39-48 in Florensov, N.A.(ed.), Mesozoic and Cenozoic Lakes of Siberia. Nauka, Moscow.

Farris, J.S.1969. A successive approximations approach to character weighting. Systematic Zoology 18:374-385.

Filippi, L.S., Canudo, J. I., Salgado, L.J., Garrido, A.C., Garcia, R.A., Cerda, I.A., and Otero, A.2011. A new sauropod titanosaur from the Plottier Formation (Upper Cretaceous) of Patagonia (Argentina). Geologica Acta 9:1-12.

García, R.A., and Salgado, L. 2013. The titanosaur sauropods from the late Campanian-early Maastrichtian Allen Formation of Salitral Moreno, Río Negro, Argentina. Acta Palaeontologica Polonica 58:269-284.

Gomani, E. M. 1999. Sauropod caudal vertebrae from Malawi, Africa; pp. 235-248 in Tomida, Y., Rich, T. H. V., and Vickers-Rich, P. (eds.), Proceedings of the Second Gondwanan Dinosaur Symposium. National Science Museum Monographs. National Science Museum of Tokyo.

Gomani, E. M.2005. Sauropod dinosaurs from the Early Cretaceous of Malawi, Africa. Palaeontologia Electronica 8:27A.

González Riga, B.J.2003. A new titanosaur (Dinosauria, Sauropoda) from the Upper Cretaceous of Mendoza, Argentina. Ameghiniana 40:155-172.

Gorscak, E., and O'Connor, P.M. 2016. Time-calibrated models support congruency between Cretaceous continental rifting and titanosaurian evolutionary history. Biology Letters 12:1-5.

Ivanov, B.A. 1940. O vozraste uglenostnykh otlozhenii Zabaikalya [On the age of the carboniferous deposits of Transbaikalia]. Sovetskaya $\mathrm{Ge}$ ologiya 11:45-54.
Kellner, A. W.A., and de Azevedo, S.A. K. . 1999. A new sauropod dinosaur (Titanosauria) from the Late Cretaceous of Brazil; pp. 111-142 in Tomida, Y., Rich, T.H.V., and Vickers-Rich, P. (eds.), Proceedings of the Second Gondwana Dinosaur Symposium. National Science Museum Monographs, Tokyo.

Kellner, A.W.A., Campos, D.A., and Trotta, M.N. F.2005. Description of a titanosaurid caudal series from the Bauru Group, Late Cretaceous of Brazil. Arquivos do Museu Nacional, Rio de Janeiro 63:529-564.

Lacovara, K. J., Lamanna, M.C., Ibiricu, L. M., Poole, J.C., Schroeter, E. R., Ullmann, P.V., Voegele, K. K., Boles, Z. M., Carter, A. M., Fowler, E.K., Egerton, V.M., Moyer, A.E., Coughenour, C.L., Schein, J. P., Harris, J. D., Martínez, R. D., and Novas, F. E. 2014. A gigantic, exceptionally complete titanosaurian sauropod dinosaur from Southern Patagonia, Argentina. Scientific Reports 4:6196.

Le Loeuff, J., Suteethorn, S., and Buffetaut, E. 2013. A new sauropod dinosaur from the Albian of Le Havre (Normandy, France). Oryctos 10:23-30.

Mannion, P.D. 2011. A reassessment of Mongolosaurus haplodon Gilmore, 1933, a titanosaurian sauropod dinosaur from the Early Cretaceous of Inner Mongolia, People's Republic of China. Journal of Systematic Palaeontology 9:355-378.

Mannion, P.D., Upchurch, P., Barnes, R. N., and Mateus, 0.2013. Osteology of the Late Jurassic Portuguese sauropod dinosaur Lusotitan atalaiensis (Macronaria) and the evolutionary history of basal titanosauriforms. Zoological Journal of the Linnean Society 168:98-206.

Martinelli, A. G., and Forasiepi, A. M. 2004. Late Cretaceous vertebrates from Bajo de Santa Rosa (Allen Formation), Rio Negro province, Argentina, with the description of a new sauropod dinosaur (Titanosauridae). Revista del Museo Argentino de Ciencias Naturales Nueva Serie 6:257-305.

Müller, K. F. 2007. PRAP, Parsimony Ratchet Analysis using PAUP*. Version 2.0b3. [updated at http://systevol.nees.unibonn.de/software/ PRAP].

Nesov, L.A.1995. Dinozavry Severnoi Evrazii: novye dannye o sostave kompleksov, ekologii i paleobiogeografii [Dinosaurs of Northern Eurasia: New Data about Assemblages, Ecology and Paleobiogeography]. 156 pp. Izdatelstvo Sankt-Peterburgskogo Universiteta, Saint Petersburg.

Nesov, L.A., and Starkov, A. I. 1992. Melovye pozvonochnye iz Gusinoozerskoi kotloviny Zabaikalya i ikh znachenie dlya opredeleniya vozrasta i uslovii obrazovaniya otlozhenii [Cretaceous vertebrates of the Gusinoe Lake Depression in Transbaikalia and their contribution into dating and determination of sedimentation conditions]. Geologiya $i$ Geophysica 6:10-19.

Powell, J.E.1992. Osteologia de Saltasaurus loricatus (SauropodaTitanosauroda) del Cretacico Superior del Noreostre Argentino; pp. 165-230 in Sanz, J. L., and Buscalioni, A.D. (eds.), Los Dinosaurios y Su Entorno Biotico: Actas del Segundo Curso de Paleontologia in Cuenca. Instituto "Juan de Valdes" Excmo, Cuenca, Argentina.

Powell, J.E. 2003. Revision of South American titanosaurid dinosaurs: palaeobiological, palaeobiogeographical and phylogenetic aspects. Records of the Queen Victoria Museum 111:1-173.

Riabinin, A. N. 1914. Zametka o dinozavre iz Zabaikalya [Note on a dinosaur from Transbaikalia]. Trudy Geologicheskogo Museya imeni Petra Velikogo Imperatorskoi Akademii Nauk 8:133-139.

Salgado, L., Apesteguia, S., and Heredia, S. E. 2005. A new specimen of Neuquensaurus australis, a Late Cretaceous saltasaurine titanosaur from North Patagonia. Journal of Vertebrate Paleontology 25:623-634.

Salgado, L., and Azpilicueta, C. 2000. Un nuevo saltasaurino (Sauropoda, Titanosauridae) de la provincia de Río Negro (Formacíon Allen, Cretácico Superior), Patagonia, Argentina. Ameghiniana 37:259-264. 
Salgado, L., Coria, R.A., and Calvo, J. O.1997. Evolution of the titanosaurid sauropods I: Phylogenetic analysis based on the postcranial evidence. Ameghiniana 34:3-32.

Santucci, R. M., and Bertini, R. J. 2006. A new titanosaur from western São Paulo State, Upper Cretaceous Bauru Group, south-east Brazil. Palaeontology 49:59-66.

Santucci, R.M., and De Arruda-Campos, A.C.2011. A new sauropod (Macronaria, Titanosauria) from the Adamantina Formation, Bauru Group, Upper Cretaceous of Brazil and the phylogenetic relationships of Aeolosaurini. Zootaxa 3085:1-33.

Sanz, J.L., Powell, J.E., Le Loeuff, J., Martinez, R., and Pereda Suberbiola, X.1999. Sauropod remains from the Upper Cretaceous of Laño (north central Spain). Titanosaur phylogenetic relationships. Estudios del Museo de Ciencias Naturales de Alava 14:235-255.

Swofford, D.L. 2002. PAUP*. Phylogenetic Analysis Using Parsimony (*and Other Methods). Version 4.0. Sinauer Associates, Sunderland.

Tschopp, E., Mateus, O., and Benson, R. B. J. 2015. A specimen-level phylogenetic analysis and taxonomic revision of Diplodocidae (Dinosauria, Sauropoda). PeerJ 3:e857.

Upchurch, P. 1998. The phylogenetic relationships of sauropod dinosaurs. Zoological Journal of the Linnean Society 124:43-103.

Upchurch, P., Barrett, P. M., and Dodson, P. 2004. Sauropoda; pp. 259322 in Weishampel, D. B., Dodson, P., and Osmolska, H. (eds.), The
Dinosauria. Second Edition. University of California Press, Berkeley, Los Angeles, London.

Upchurch, P., and Martin J. 2003. The anatomy and taxonomy of Cetiosaurus (Saurischia, Sauropoda) from the Middle Jurassic of England. Journal of Vertebrate Paleontology 23:208-231.

Wedel, M. J., Cifelli, R. L., and Sanders, R.K.2000. Osteology, paleobiology, and relationships of the sauropod dinosaur Sauroposeidon. Acta Palaeontologica Polonica 45:343-388.

Whitlock, J.A. 2011. Re-evaluation of Australodocus bohetii, a putative diplodocoid sauropod from the Tendaguru Formation of Tanzania, with comment on Late Jurassic sauropod faunal diversity and palaeoecology. Palaeogeography, Palaeoclimatology, Palaeoecology 309:333-341.

Wilson, J.A. 2002. Sauropod dinosaur phylogeny: critique and cladistic analysis. Zoological Journal of the Linnean Society 136:217-276.

Wilson, J.A., and Sereno, P. C. 1998. Early evolution and higher-level phylogeny of sauropod dinosaurs. Journal of Vertebrate Paleontology 18:1-72.

Wilson, J.A., and Upchurch, P.2009. Redescription and reassessment of the phylogenetic affinities of Euhelopus zdanskyi (Dinosauria: Sauropoda) from the Early Cretaceous of China. Journal of Systematic Palaeontology 7:199-239.

You, H., Li, D., Zhou, L., and Ji, Q. 2008. Daxiatitan binglingi: a giant sauropod dinosaur from the Early Cretaceous of China. Gansu Geology 17:1-10.

\section{Appendix 1. Characters scored for Tengrisaurus starkovi gen. et sp. nov.}

188(0): Caudal bone texture: solid.

189(1): Caudal transverse processes: disappear by caudal 15.

193(3): Anterior caudal centra (excluding the first), articular face shape: procoelous.

196(0): Anterior and middle caudal vertebrae, ventrolateral ridges: absent.

197(0): Anterior and middle caudal vertebrae, triangular lateral process on the neural spine: absent.

199(1): Anterior caudal neural spines, transverse breadth: greater than anteroposterior length.

200(1): Anterior caudal transverse processes, proximal depth: deep, extending from centrum to neural arch.

203(1): Anterior caudal vertebrae, hyposphene ridge: present.

205(0): Anterior caudal neural arches, spinoprezygapophyseal lamina (sprl): absent, or present as small short ridges that rapidly fade out into the anterolateral margin of the spine.

206(0): Anterior caudal neural arches, spinoprezygapophyseal lamina (sprl)-spinopostzygapophyseal lamina (spol) contact: absent.

207(1): Anterior caudal neural arches, prespinal lamina (prsl): present.

208(0): Middle caudal centra, shape: cylindrical.

209(0): Anterior and middle caudal centra, ventral longitudinal hollow: absent.

210(3): Middle caudal centra, articular face shape: procoelous.

211(1): Middle caudal vertebrae, location of the neural arches: on the anterior half of the centrum.

212(0): Middle caudal vertebrae, height of the pedicels below the prezygapophysis: low with curved anterior edge of the pedicel.

213(2): Middle caudal vertebrae, orientation of the neural spines: slightly directed posteriorly.

215(0): Middle caudal vertebrae, ratio of centrum length to centrum height: less than 2, usually 1.5 or less. 